\title{
Kantor Pusat Badan Ekonomi Kreatif Dengan Pendekatan ARSITEKTUR BERKELANJUTAN Di JAKARTa
}

\author{
Daniel Tantama Putro, Hardiyati, Leny Pramesti \\ Program Studi Arsitektur \\ Universitas Sebelas Maret Surakarta \\ Email : danieltantamaps@yahoo.co.id
}

\begin{abstract}
ASEAN Economy Community is a great opportunity for each country in ASEAN to expand its economy. These opportunities are not only related to trade market, but also in services market, experts, investment and capital flows. However behind these opportunities, not a few countries in ASEAN respond the open market or free market of ASEAN become a threat. Badan Ekonomi Kreatif (Bekraf) was established as a government effort to overcome ASEAN free market, which creative economy is Indonesia economy focus nowadays. Since was establishes at early 2015, Bekraf has been quite instrumental in moving the creative economy in Indonesia. Headquarter planning becomes important not only to facilitate Bekraf, but also supports the development of creative economy in Indonesia to compete in the free market of ASEAN. But now in the planning and design issues have become more widespread, namely environmental problems. Jakarta as government center, the location of the site is a crowded city, have limited land, little green open space, and a variety of other environmental problems. These conditions make the construction of new buildings in Jakarta becomes irrelevant. Sustainable Architecture approach is right solution because this approach has the ability to address environmental issues with sustainable resources which aims to improve the quality of the natural and human. The problem in this design is how to present principle of Sustainable Architecture at office and commercial building typology. Planning and design Bekraf Headquarter use connectivity, indigenous, and long life, loose fit methods which are three principle of Sustainable Architecture. Design applications of Sustainable Architecture at Bekraf Headquarter processed through strategy of Sustainable Architecture, those are sustainable land use, sustainable material, sustainable energy, sustainable water, sustainable health and well-being, and sustainable community. The strategy of Sustainable Architecture building design embodies a minimal pavement at the site, the contours of landscape, using modular and renewable materials, rosters design and mass openness to optimize cross ventilation and natural lighting, wastewater treatment pond design, structuring elements of vegetation, accessibility design, building automation systems, as well as the design of corridors into public spaces.
\end{abstract}

Keywords: Badan Ekonomi Kreatif, Connectivity, Creative Economy, Indigenous, Long Life, Loose Fit, Sustainable Architecture

\section{PENDAHULUAN}

Masyarakat Ekonomi ASEAN (MEA) merupakan integrasi ekonomi di ASEAN, yang didasarkan pada konvergensi kepentingan negara-negara anggota ASEAN. Kondisi seperti ini membentuk ekonomi terbuka atau pasar bebas, tidak hanya dalam perdagangan tetapi juga jasa, tenaga ahli, investasi, dan aliran modal. Hal ini memunculkan banyaknya barang impor yang akan mengalir ke Indonesia dan akan mengancam industri lokal dalam bersaing dengan produk-produk luar negeri yang jauh lebih berkualitas. Isu tersebut menggerakkan pemerintah Indonesia mencanangkan konsep ekonomi kreatif sebagai usaha persaingan pasar bebas ASEAN. Pengembangan ekonomi kreatif ini didukung dengan pembentuk sebuah Lembaga Pemerintahan Non Kementerian yaitu Badan Ekonomi Kreatif (Bekraf).

Di Indonesia, ekonomi kreatif memiliki potensi besar sebagai kekuatan dalam pengembangan perekonomian. Ekonomi kreatif merupakan penyumbang PDB Atas Dasar Harga Berlaku (ADHB) terbesar ketujuh dari sepuluh sektor ekonomi penyumbang pertumbuhan ekonomi. Pada tahun 2010-2013, nilai PDB Atas Dasar Harga Berlaku (ADHB) 
ekonomi kreatif rata-rata sebesar 555 triliun dengan kontribusi rata-rata 7,15 terhadap nilai nasional. Hal ini didorong oleh pertumbuhan jumlah usaha di sektor industri kreatif pada periode tersebut sebesar 1\%, sehingga jumlah industri kreatif pada tahun 2013 tercatat sebanyak 5,4 juta usaha yang menyerap angkatan kerja sebanyak 12 juta. Pada segi sumber daya manusia, jumlah orang kreatif di Indonesia sudah meningkat, namun ketersediaan dan kualitas orang kreatif masih belum memadai untuk dapat meningkatkan skala produksi industri kreatif. Lemahnya kualitas produk kreatif lokal pun membuat masyarakat lebih memilih untuk mengonsumsi produk kreatif dunia disbanding produk dalam negeri.

Potensi dan permasalahan ini menjadi isu yang perlu segera ditangani dengan memfasilitasi Bekraf sebagai lembagai khusus ekonomi kreatif untuk menjadi wadah utama dalam pengembangan ekonomi kreatif dengan didukung wadah secara fisik sebagai ruang produktif bagi Bekraf untuk melaksanakan fungsinya berdasarkan Perpres Nomor 72 Pasal 3 Tahun 2015. Wadah ekonomi kreatif ini harus pula disertai dengan fasilitasi rantai nilai pengembangan ekonomi kreatif yang dimulai dari tahap kreasi, produksi, distribusi, konsumsi, hingga konservasi, dan wadah ini harus berbasis pada konsep pengembangan ekonomi kreatif di Indonesia, quad-helix, yang mencakup keterlibatan intelektual, pelaku usaha, komunitas dan pemerintah.

Jakarta sebagai Ibukota Indonesia menjadi lokasi terpilih dalam perencanaan dan perancangan kantor pusat ini. Jakarta memiliki berbagai titik strategis yang akan memudahkan pengembangan ekonomi kreatif di Indonesia. Kondisi Kota Jakarta saat ini memiliki banyak permasalahan lingkungan, seperti ingkat pembangunan tinggi, kurangnya lahan terbuka hijau, kepadatan transportasi dan tingkat polusi tinggi, membuat pembangunan gedung baru di Jakarta menjadi tidak relevan. Namun Kota Jakarta dengan potensi sebagai titik awal pengembangan ekonomi kreatif di Indonesia perlu menjadi pertimbangan. Maka Arsitektur Berkelanjutan menjadi pendekatan pada perencanaan dan perancangan.

Arsitektur Berkelanjutan merupakan pendekatan desain yang didasari oleh sistem alam dan terkait pada semua hal terhadap penempatan perancangan. Pada buku Sustainable Design: Ecology, Architecture, and Planning, Williams (2007) mengatakan, "Sustainable designs sustain-sustainable design sustains". Hal ini dikatakan bahwa Arsitektur Berkelanjutan tidak hanya mengatasi kondisi lingkungan namun tetap dapat berfungsi terhadap keterbatasan sumber daya. Williams (2007) juga mengatakan terdapat tiga prinsip dasar dalam proses desain Arsitektur Berkelanjutan, yaitu connectivity, indigenous, dan long life, loose fit.

Tiga prinsip ini menjadi dasar pertimbangan dalam proses perencanaan dan perancangan kantor pusat, sehingga desain dapat hadir secara efisien terhadap penggunaan energi, lahan, material, teknologi, dan pemanfaatan sumber daya terbarukan secara optimal. Kantor Pusat Bekraf dapat pula menjadi bangunan mandiri yang mampu meningkatkan kualitas alam dan manusia.

\section{METODE}

Penyusunan konsep perencanaan dan perancangan Kantor Pusat Badan Ekonomi Kreatif dengan Pendekatan Arsitektur Berkelanjutan di Jakarta dilakukan melalui metode:

1. Penelusuran gagasan awal melalui studi isu dan fenomena Masyarakat Ekonomi ASEAN, ekonomi kreatif di Indonesia, dan Badan Ekonomi Kreatif.

2. Penentuan pendekatan Arsitektur Berkelanjutan dari hasil studi isu lingkungan dan keterbatasan energi secara global, khususnya Jakarta sebagai kota pusat pemerintahan.

3. Studi lapangan dan wawancara terkait Badan Ekonomi Kreatif, kegiatan ekonomi kreatif, dan bangunan sebagai preseden. Metode ini dilakukan untuk: (1) mengetahui struktur dan sistem organisasi Bekraf dan harapan langsung Bekraf pada perencanaan kantor pusat; (2) mengetahui kondisi dan suasana kegiatan ekonomi kreatif secara fisik dan non fisik; (3) menentukan ragam kegiatan ekonomi kreatif yang akan diwadahi; (4) mengetahui kondisi dan sistem operasional bangunan kantor dan komersial; dan (5) menentukan ragam kegiatan pada bangunan kantor yang akan diwadahi. 
4. Studi pustaka yang berkaitan dengan bangunan kantor dan komersial, Badan Ekonomi Kreatif, Kota Jakarta, dan teori Arsitektur Berkelanjutan melalui buku, peraturan, ketetapan, perundangundangan, jurnal, skripsi, dan artikel untuk merumuskan strategi desain.

5. Perumusan permasalahan dan persoalan yang akan diselesaikan dalam desain.

6. Analisis konsep perencanaan dan perancangan dengan pertimbangan tiga elemen utama, yaitu: (1) Arsitektur Berkelanjutan sebagai pendekatan; (2) Kantor Pusat sebagai obyek utama yang akan direncanakan dan dirancang; dan (3) Wadah ekonomi kreatif sebagai obyek pendukung Kantor Pusat yang akan direncanakan dan dirancang. Analisis pada tiga elemen utama dilakukan berdasarkan tiga prinsip Arsitektur Berkelanjutan, yaitu connectivity, indigenous, dan long life, loose fit.

7. Perumusan hasil analisis dalam bentuk konsep kegiatan, pelaku, peruangan, olah tapak dan tata massa, olah bentuk dan lansekap, utilitas, struktur, dan penerapan konsep strategi Arsitektur Berkelanjutan, yaitu sustainable land use, sustainable material, sustainable energy, sustainable water, sustainable healt and well being, dan sustainable community.

\section{ANALISIS}

\subsection{Analisis Pelaku Kegiatan}

Pelaku kegiatan atau pengguna dalam bangunan secara umum terbagi menjadi pengelola bangunan, pengurus organisasi Badan Ekonomi Kreatif, penyewa bangunan dan pengunjung bangunan. Pengguna tersebut terdapat di beberapa kelompok kegiatan di kawasan Kantor Pusat Bekraf yang merupakan hasil penjabaran dari Perpres No.2 Tahun 2015 yang menyatakan arah kebijakan pembangunan ekonomi kreatif adalah memfasilitasi Orang Kreatif (OK) di sepanjang rantai nilai yang dimulai dari tahap kreasi, produksi, distribusi, konsumsi, hingga konservasi. Kelompok kegiatan tersebut terdiri dari kelompok kegiatan kantor pusat, kelompok kegiatan kantor sewa, kelompok kegiatana ruang kreatif (creative place), kelompok kegiatan area pembuat (maker space), kelompok kegiatan ruang belanja (market place), dan kelompok kegiatan pusat komunitas (community hub).

\subsection{Analisis Peruangan}

Pada analisis ini didapat beberapa pokok kebutuhan ruang berdasarkan Perpres No.2 Tahun 2015 yang diilustrasikan pada Gambar 1.

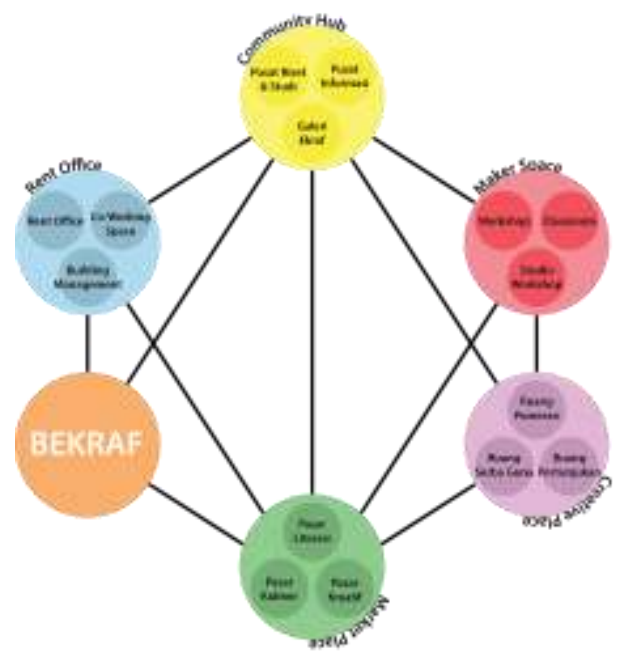

Gambar 1. Analisis Hubungan Makro

\section{Kantor Pusat Bekraf}

Kantor pusat dihadirkan untuk pengelola Bekraf, yaitu kepala, wakil kepala, sekretariat, deputi dan para pelaku kegiatan lain dan para kepala departemen dan staff dalam Laboratorium Ekonomi Kreatif. Bagian ini pun terdapat ruang pengelola bangunan dan ruang penunjang, seperti ruang rapat, ruang pertemuan dan ruang pendukung lain.

2. Kantor Sewa

Kantor sewa, merupakan ruang kosong yang akan disewakan dan digunakan sebagai kantor bagi perusahaan atau pemakai dalam jangka waktu tertentu. Kantor sewa terdiri dari dua jenis, yang pertama ruang yang lebih bersifat lebih privat dan co-working space yang bersifat lebih terbuka, fleksibel dan kolaborasi.

3. Ruang Kreatif (Creative Place)

Pada ruang kreatif terdapat ruang pameran atau galeri karya dan ruang pertunjukan berupa gedung teater dan area teater terbuka.

4. Area Pembuat (Maker Space)

Ruang ini menjadi area bagi para penggiat kreatif untuk melakukan 
kegiatan percobaan, pelatihan dan pengembangan diri yang difasilitasi dengan ruang kelas, ruang studio dan bengkel kerja.

5. Ruang Belanja (Market Place)

Ruang belanja adalah ruang karya kreatif diperjualbelikan yang terdiri dari beberapa zona ruang, yaitu pasar kreatif, pasar kuliner dan pasar literasi.

6. Pusat Komunitas

Pusat komunitas menjadi ruang berkumpul bagi para komunitas untuk mengembangkan ekonomi kreatif berupa ruang riset dan studi, ruang informasi dan residensial atau penginapan.

\subsection{Analisis Lokasi}

\subsubsection{Pemilihan Lokasi}

Pada pemilihan lokasi terdapat beberapa alternatif lokasi yang terdiri dari Kecamatan Kebayoran Baru, Kecamatan Kebayoran Lama dan Kecamatan Menteng. Tiga alternatif lokasi tersebut dipilih salah satunya melalui analisis kriteria alternatif lokasi pada Tabel 1 berdasarkan nilai prinsip Arsitektur Berkelanjutan tertinggi. Lokasi terpilih yaitu lokasi di Kecamatan Kebayoran Baru dengan nomor kavling 017.K1.a.b yang berada di Jalan Jenderal Sudirman dan Jalan Senopati, Jakarta Selatan

Tabel 1. Kriteria Alternatif Lokasi

\begin{tabular}{|c|c|c|c|}
\hline KRITERIA & 1 & 2 & 3 \\
\hline \multirow{9}{*}{$\begin{array}{l}\text { Kawasan strategis } \\
\text { perkantoran dan } \\
\text { pemerintahan } \\
\text { Kondisi sarana dan } \\
\text { prasarana sekitar lokasi } \\
\text { Kedekatan titik strategis } \\
\text { sasaran usia produktif } \\
\text { Kemudahan akses } \\
\text { transportasi pribadi } \\
\text { Kemudahan akses } \\
\text { transportasi umum } \\
\text { Potensi pengembangan } \\
\text { TOD } \\
\text { Tingkat kenyamanan } \\
\text { kepadatan } \\
\text { Tingkat kenyamanan } \\
\text { kebisingan } \\
\text { Fleksibilitas } \\
\text { pengembangan lahan objek }\end{array}$} & $\bullet$ & & $\bullet$ \\
\hline & $\bullet \bullet \bullet$ & $\bullet \bullet \bullet$ & $\bullet \bullet$ \\
\hline & & $\bullet \bullet \bullet$ & $\bullet \bullet \bullet$ \\
\hline & $\bullet \cdots$ & & $\bullet \bullet$ \\
\hline & $\bullet \bullet \bullet$ & $\bullet \bullet$ & $\bullet \bullet \bullet$ \\
\hline & $\bullet \bullet$ & $\bullet$ & $\bullet \bullet$ \\
\hline & $\bullet \bullet$ & $\bullet$ & $\bullet \bullet$ \\
\hline & $\bullet$ & $\bullet$ & \\
\hline & & & \\
\hline
\end{tabular}

Potensi kondisi alam sekitar lokasi

Luasan lokasi terhadap intensitas lahan Jumlah

\subsubsection{Pengolahan Lahan}

Pada pengolahan dilakukan dengan analisis pencapaian tapak dan pola sirkulasi, analisis pandangan dan orientasi, analisis kebisingan, dan analisis klimatologi yang berdasarkan prinsip Arsitektur Berkelanjutan.

\subsubsection{Analisis Lansekap}

Prinsip Arsitektur Berkelanjutan pada lansekap berpengaruh pada kontekstualitas terhadap kondisi eksisting dan sekitar. Tapak terpilih yang merupakan lahan kosong tidak terawat terdapat beberapa titik pohon yang baik untuk dipertahankan. Titik eksisting pohon diilustrasikan dengan lingkaran berwarna hijau yang ditunjukan pada Gambar 2.

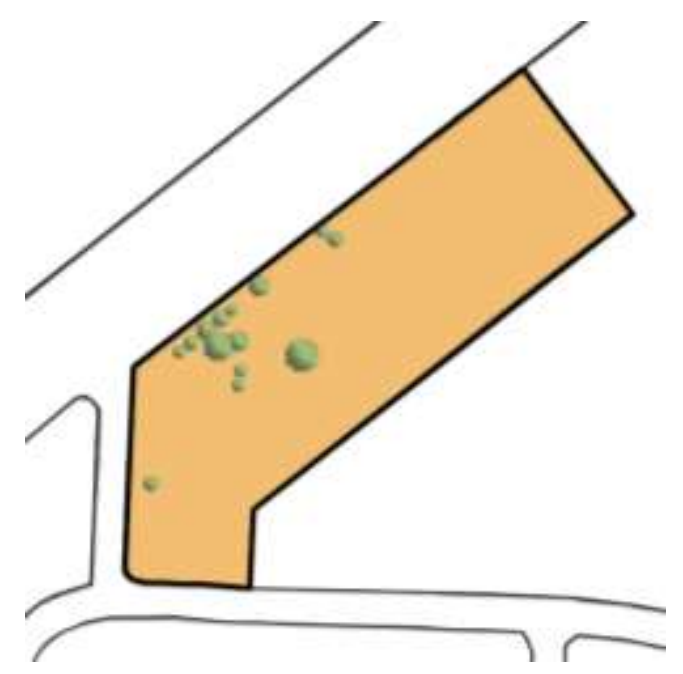

Gambar 2. Titik Eksisting Pohon

Pada analisis lansekap diperhatikan pada jenis elemen, seperti lansekap peneduh, lansekap pengarah, lansekap penutup tanah dan lansekap penyerap polusi. Tata letak dan gubahan pun diolah agar lansekap dapat berperan pada konektivitas bangunan dengan lingkungan sekitar seperti pada Gambar 3, sehingga lansekap mempengaruhi kegiatan di dalam tapak. Terdapat empat area secara umum yang menjadi prioritas gubahan dan tata lansekap, yaitu pintu masuk, area transisi, atrium dan balkon. 


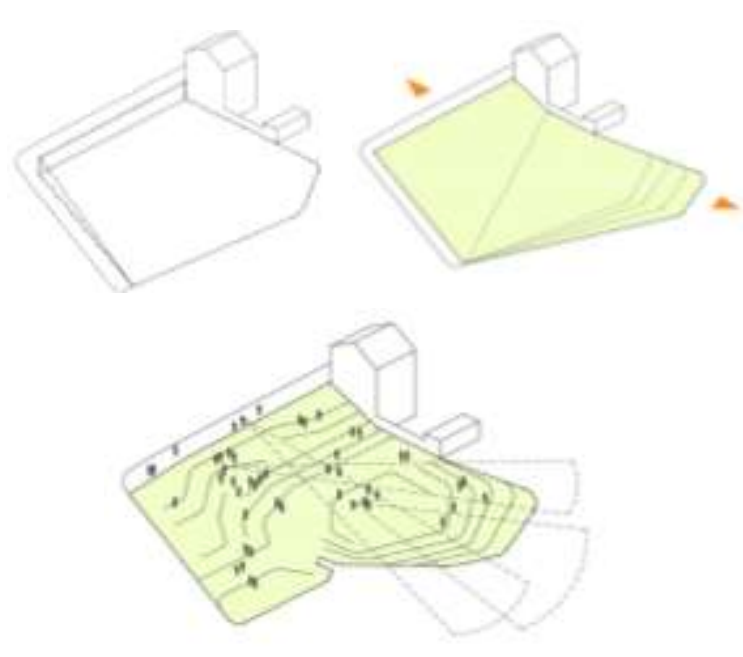

Gambar 3. Konektivitas Lansekap

\subsection{Analisis Bentuk}

Analisis bentuk bertujuan untuk mendapatkan bentuk dan tampilan massa yang berdasarkan Arsitektur Berkelanjutan. Pada prinsip Arsitektur Berkelanjutan, bentuk massa perlu dihadirkan konektivitas terhadap alam, iklim, tapak dan sekitar tapak secara visual dan program kegiatan. Gambar 4 memunjukan konektivitas dihadirkan dengan pengintegrasian antar ruang pada bangunan serta integrasi pada bangunan sekitar tapak.

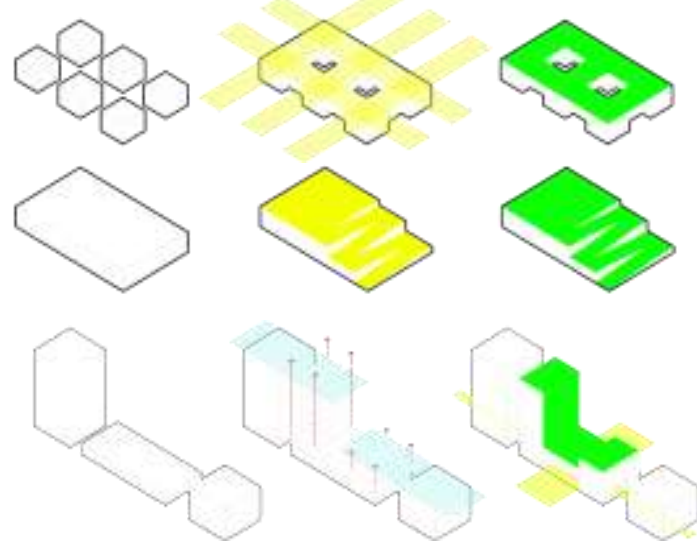

Gambar 4. Konektivitas Bentuk

Bentuk massa juga perlu diperhatikan secara komposisi bangunan, yaitu proporsi, harmonisasi, keseimbangan, kesatuan, irama dan penekanan agar dapat menghadirkan bangunan dengan visual yang enak dilihat seperti yang ditunjukan pada Gambar 4, sehingga memengaruhi kelanggengan umur bangunan.

\subsection{Analisis Struktur}

Analisis struktur bertujuan untuk menentukan sistem keseluruhan struktur pada bangunan yang berdasarkan beban yang harus didukung, kondisi tanah, bentuk dan dimensi vertikal bangunan, karakter bangunan, dan pengaruh terhadap lingkungan sekitar.

\section{Sub structure}

Pada bagian sub structure akan menggunakan pondasi tiang pancang atau bored pile, untuk membuat bangunan yang memiliki durabilitas lebih tinggi. Pondasi ini digunakan pada bangunan atas pertimbangan ketinggian yang lebih dari 4 lantai dan memiliki basement.

\section{Super Structure}

Rigid frame yang ditunjukan pada Gambar 5 menjadi struktur yang mendominasi pada super structure area kantor dan market place, dan diperkuat oleh core yang menjadi pusat akses sirkulasi vertikal. Pada area maker space dan creative place menggunakan struktur bentang lebar untuk meminimalisir kolom.

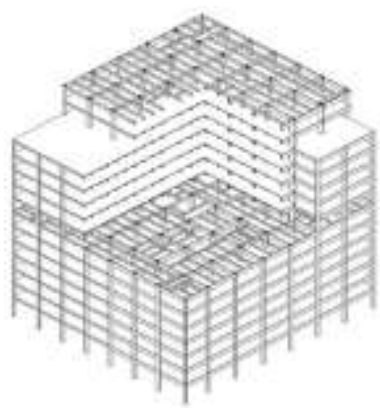

Gambar 5. Analisis Super Structure

\section{Upper Structure}

Struktur atap yang digunakan dibagi tiga jenis berdasarkan kebutuhan berdasarkan ketinggian dan luas ruang, yaitu green roof, atap dak, dan waffle structure yang diletakan pada area maker space dan creative place. Waffle structure yang ditunjukan pada Gambar 6 digunakan sebagai struktur atap pada bentang lebar untuk mengurangi penggunaan kolom pada bangunan. 


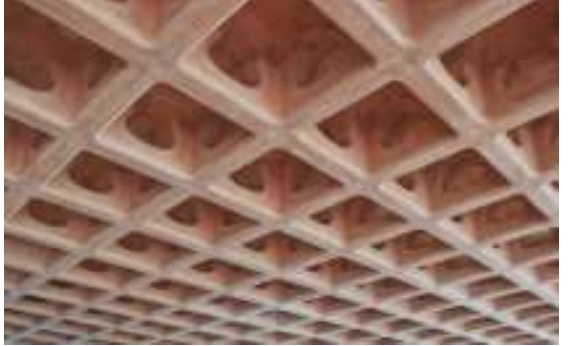

Gambar 6. Analisis Upper Structure: Waffle Structure

Green roof yang memiliki lapisan struktur seperti pada Gambar 7 digunakan pada bagian atap yang dimanfaatkan sebagai ruang publik dan ruang terbuka hijau bagi para pengguna bangunan.

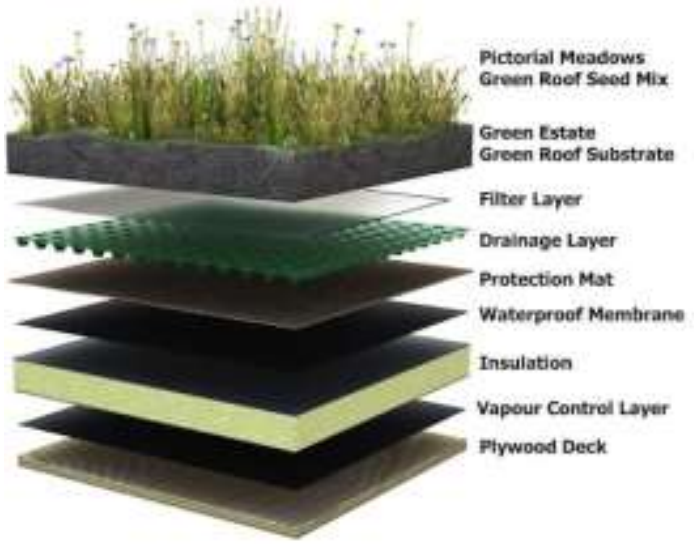

Gambar 7. Analisis Upper Structure: Green Roof Structure

\subsection{Analisis Arsitektur Berkelanjutan}

Pendekatan Arsitektur Berkelanjutan yang digunakan berdasarkan tiga prinsip, yaitu connectivity, indigenous, dan long life, loose fit. Prinsip connectivity bertujuan untuk memperkuat hubungan antara obyek perancangan pada tapak dan sekitarnya, komunitas, dan ekologi. Prinsip indigenous bertujuan untuk menghadirkan perencanaan dan perancangan yang dibuat 'dengan' dan 'untuk' apa yang sudah ada dan berlangsung sebelumnya pada tapak. Prinsip long life, loose fit bertujuan untuk menghadirkan perencanaan dan perancangan yang memiliki karakter yang cocok di rentang waktu panjang, tercermin dari generasi sebelumnya hingga generasi yang akan datang. Kemudian prinsip ini diolah melalui enam strategi Arsitektur Berkelanjutan yang dikatakan oleh Sassi (2006) berdasarkan buku Strategies for Sustainable Architecture.
1. Analisis Sustainable Land Use

Analisis sustainable land use bertujuan untuk melakukan efisiensi pemanfaatan lahan, pengembangan mixed-use, integrasi pada titik strategis sekitar tapak, serta pertimbangan dampak perencanaan dan perancangan terhadap tapak sekitar.

2. Analisis Sustainable Material

Analisis sustainable material bertujuan untuk menghadirkan perencanaan dan perancangan yang mampu memanfaatkan daur ulang limbah material, material alam terbarukan, dan penggunaan material yang memiliki dampak rendah terhadap lingkungan.

3. Analisis Sustainable Energy

Analisis sustainable energy atau energi berkelanjutan bertujuan untuk mendapakan perencanaan dan perancangan yang mampu mengaplikasikan desain hemat energi, pemanfaatan sumber daya terbarukan, serta minim dampak lingkungan, sehingga mampu meningkatkan kualitas hidup.

4. Analisis Sustainable Water

Analisis sustainable water bertujuan untuk memanfaatkan air sebagai sumber energi terbarukan dengan mengurangi kebutuhan air, dan memanfaatkan sumber air alternatif, seperti grey water, black water, dan air hujan.

5. Analisis Sustainable Health and Well Being

Pada analisis ini bertujuan menghadirkan perencanaan dan perancangan yang memiliki kondisi lingkungan sehat. Kondisi lingkungan tidak hanya terhindar dari penyakit namun juga pada psikologis dan rasa bahagia pengguna dengan memberikan lingkungan yang menyenangkan, memberi ketenangan jiwa, dan menghadirkan sentuhan alam untuk meningkatkan kualitas dan pengalaman hidup tiap individu.

6. Analisis Sustainable Community

Analisis sustainable community atau komunitas berkelanjutan bertujuan dalam pengembangan berkelanjutan secara lebih luas melalui masyarakat dengan cara menghadirkan partisipasi masyarakat, pelatihan, arsitektur yang meningkatkan kualitas hidup dan promosi. 


\section{KESIMPULAN (KONSEP DESAIN)}

Konsep desain menitikberatkan pada pembentukan Arsitektur Berkelanjutan berdasarkan tiga prinsip, yaitu connectivity, indigenous, dan long life, loose fit melalui enam strategi Arsitektur Berkelanjutan, yaitu sustainable land use, sustainable energy, sustainable water, sustainable material, sustainable health and well being, dan sustainable community.

1. Data Obyek Rancangan

Obyek rancangan adalah Kantor Pusat Badan Ekonomi Kreatif (Bekraf HQ) yang berlokasi di Jalan Sudirman dan Jalan Senopati, Kecamatan Kebayoran Baru, Jakarta. Obyek rancangan memiliki luas lahan 27164,8 $\mathrm{m}^{2}$, luas bangunan $169584.32 \mathrm{~m}^{2}$, dan tinggi bangunan 176.65 $\mathrm{m}^{2}$. Obyek rancangan memiliki kegiatan utama sebagai kantor pusat yang didukung kegiatan-kegiatan pengembangan ekonomi kreatif, seperti rent office, market place, maker space, creative place, dan community hub.

2. Konsep Arsitektur Berkelanjutan

Pendekatan Arsitektur Berkelanjutan hadir pada konsep desain dalam bentuk pengolahan tapak, pengolahan bentuk dan lansekap, pemanfaatan material terbarukan, pemanfaatan energi berkelanjutan, dan berbagai detail desain lain berdasarkan strategi Arsitektur Berkelanjutan seperti yang sudah disebutkan dibagian sebelumnya.

Pada Gambar 8 menunjukan Arsitektur Berkelanjutan pada pengolahan bentuk dan lansekap untuk mengundang masuknya kegiatan pada tapak. Sustainable health and well being dan sustainable energy dihadirkan dengan keterbukaan ruang dalam terhadap arah sinar matahari dan angin, serta penghadiran elemen air sebagai pengontrol iklim mikro, yang ditunjukan pada Gambar 9.

Arsitektur Berkelanjutan juga dihadirkan dengan ruang publik terbuka hijau seperti pada Gambar 10, yang menunjukan sustainable community. Pada Gambar 10 juga menunjukan penggunaan material modular sebagai material utama pada bangunan. Hasil akhir desain Kantor Pusat Badan Ekonomi Kreatif dengan
Pendekatan Arsitektur Berkelanjutan di Jakarta dapat dilihat pada Gambar 11.

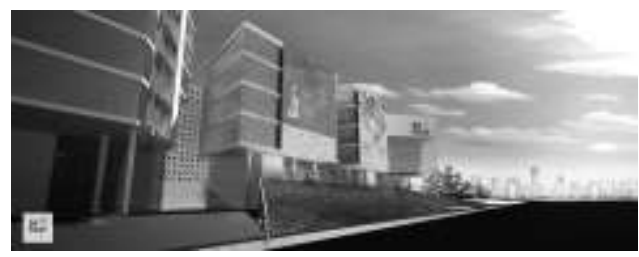

Gambar 8. Area Entrance Bekraf HQ

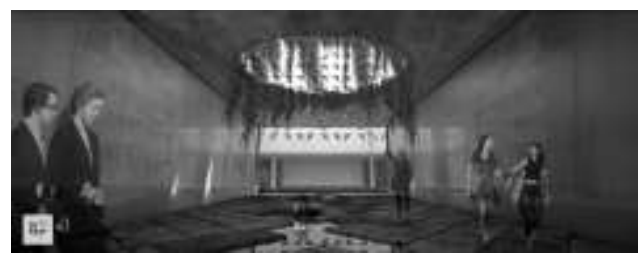

Gambar 9. Koridor Penerima Market Place Bekraf HQ

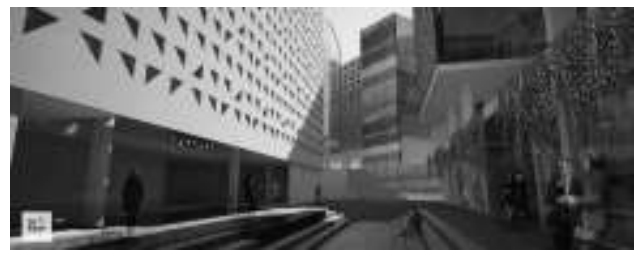

Gambar 10. Plaza Utama Bekraf HQ

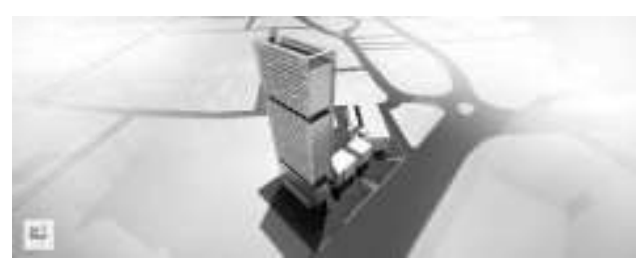

Gambar 11. Perspektif Mata Burung Bekraf HQ

\section{REFERENSI}

Kemenparekraf. 2014. Ekonomi Kreatif: Kekuatan Baru Indonesia Menuju 2025. Jakarta: Kemenparekraf.

Sassi, Paola. 2006. Strategies for Sustainable Architecture. USA: Taylor \& Francis Inc.

Williams, Daniel E. 2007. Sustainable Design: Ecology, Architecture, and Planning. New Jersey: John Willey \& Sons. 